\title{
KONFLIK TANAH DI DAERAH OTONOM BARU (DOB) STUDI KONFLIK TANAH PEMBANGUNAN KANTOR DPRD DI KABUPATEN NAGEKEO, PROVINSI NUSA TENGGARA TIMUR
}

\author{
Fransiskus X. Gian Tue Mali \\ Gfrank25.gf@gmail.com \\ Program Studi Ilmu Politik, Universitas Kristen Indonesia, Jakarta
}

\begin{abstract}
Post implementation of regional autonomy and the impact on regional expansion, then $D O B$ will start the construction of infrastructure facilities and infrastructure for the public interest. But often in the process of conflict either in the form of the issue of compensation, land acquisition, nor the problem of land ownership. Issues such as this led to the government and people often face to face in a conflict that sometimes led to delays in economic development is the primary objective of regional expansion. Because local governments and regional elites tend to be born as a major power in the region. Along with that, the community and social groups in it was reborn as a force that is trying to fight for their rights are neglected. The study concluded that the land conflict in Nagekeo as DOB pahamnya occurs because local governments on regional autonomy meaning that governments in the region tend to be born as the arrogant powers are hiding behind reasons of public interest that is ridden by personal and group interests. Thus ignoring the rights of some communities in the area. Local authorities thus essentially a major factor in the failure of regional expansion in Nagekeo.
\end{abstract}

Keywords: Land Conflict, DOB, Nagekeo
Abstrak

Pasca penerapan otonomi daerah dan berdampak pada pemekaran daerah, maka Daerah Otonom Baru (DOB) akan mulai melakukan pembangunan sarana prasarana maupun infrastruktur bagi kepentingan publik. Namun sering dalam proses tersebut terjadi konflik baik berupa persoalan ganti rugi, pembebasan lahan, maupun masalah kepemilikan lahan. Persoalan seperti ini menyebabkan pemerintah dan masyarakat sering berhadaphadapan dalam konflik yang terkadang berujung pada terhambatnya pembangunan ekonomi yang merupakan tujuan utama dari pemekaran daerah. Karena pemda dan para elit daerah cenderung lahir sebagai kekuatan utama di daerah. Seiring dengan itupula masyarakat dan kelompok sosial di dalamnya pun lahir kembali sebagai kekuatan yang berusaha memperjuangkan hak-haknya yang terabaikan. Hasil penelitian menyimpulkan bahwa konflik tanah di Nagekeo sebagai DOB terjadi karena tidak pahamnya pemerintah daerah terhadap makna otonomi daerah sehingga pemerintah di daerah cenderung lahir sebagai kekuatan arogan yang berlindung dibalik alasan kepentingan umum yang ditunggangi oleh kepentingan pribadi dan kelompok. Sehingga mengabaikan hak sebagian masyarakat daerah. Sehingga pada hakikatnya pemerintah daerahlah faktor utama dalam kegagalan pemekaran daerah di Nagekeo.

Kata kunci : Konflik Tanah, DOB, Nagekeo

\section{Pendahuluan}

Pasca reformasi 1998 yang membawa perubahan sistem politik dan sistem pemerintahan, turut serta pula sistem pemerintahan daerah maupun hubungan pusat daerah pun mengalami perubahan. Rezim Orde Baru yang sentralistik dan cenderung protektif terhadap pemerintahan di daerah, 

Indonesia memasuki era desentralisasi, yang menganut mekanisme pembagian dan pemisahan wewenang. Pembagian dan pemisahan kewenangan ini kemudian berujung pada dibentuknya pemerintahan daerah yang otonom, yaitu daerah diberi keleluasaan untuk mengurus wilayahnya sendiri sesuai dengan potensi dan keinginan rakyat daerahnya sendiri. Dasar hukumnya ada pada UU No. 22 Tahun 1999 tentang Pemerintahan Daerah, yang kemudian direvisi menjadi UU No. 32 Tahun 2004. Namun pada hakikatnya makna pengelolahan wilayah daerah berdasarkan potensi dan keinginan rakyat daerah itu sendiri telah tersirat dalam UUD 1945 Pasal 18 B ayat 2. Meskipun pada pasal ini cenderung pengakuan terhadap nilai-nilai tradisional lokal yang diakui, seperti hukum adat beserta hak-hak tradisionalnya, selama tidak bertentangan dengan prinsip kebangsaan. Namun asas potensi daerah dan keinginan rakyat ini kemudian bergulir semakin kencang pada tuntutan daerah untuk memisahkan diri dari daerah induk dengan didasarkan pada berbagai macam faktor. Faktor seperti potensi ekonomi daerah, wilayah yang luas, perbedaan sosial budaya, minimnya pelayanan publik, hingga rendahnya partisipasi politik menjadi pemicu daerah-daerah baru bermunculan baik itu kabupaten/kota maupun provinsi. Pembentukan daerah baru ini memiliki legalitasnya pada Bab II tentang Pembentukan Daerah dan Kawasan Khusus UU No. 32 Tahun 2004.

Namun keinginan untuk pemekaran wilayah baru lebih banyak terjadi di wilayah luar pulau Jawa.
Daerah di Pulau Jawa cenderung menginginkan adanya perubahan status dari kabupaten menjadi kotamadya, di luar Jawa cenderung menginginkan pembentukan daerah baru yaitu kabupaten maupun provinsi. Kecenderungan ini pada akhirnya berdampak pada bertambahnya jumlah daerah di Indonesia. Saat ini saja jumlah daerah di Indonesia mencapai 415 kabupaten, 93 kotamadya, 1 kabupaten administrasi yaitu Kabupaten Kepulauan Seribu, dan 5 Kota Administrasi, dan 34 Provinsi.

Pintu terbukanya pemekaran daerah baru ini hakikatnya terwujud pada masa kepemimpinan presiden Abdurahman Wahid yang mengeluarkan PP No. 29 Tahun 2000. Meski pada tahun 1999 sudah terjadi pemekaran daerah yaitu pemekaran provinsi Maluku Utara dari Provinsi Maluku, dan Kabupaten Simeuleu. Dengan adanya PP No. 29 Tahun 2000 kemudian berturut-turut terbentuk 7 Provinsi baru, Provinsi Banten, Provinsi Kepulauan Bangka Belitung, Provinsi Gorontalo, Provinsi Irian Jaya Barat, Provinsi Kepulauan Riau, dan terakhir Provinsi Kalimantan Utara. Sementara jumlah kabupaten yang bertambah hingga tahun 2014 ada 181 kabupaten, dan 34 kota yang berstatus DOB. Untuk mengerem laju pemekaran daerah pemerintahan SBY mengeluarkan PP 78 Tahun 2007, namun hingga kini kemunculan daerah-daerah baru terus berlanjut.

Pemekaran daerah memang membawa dampak positif dan negatif terutama bagi DOB itu sendiri, salah satu yang paling besar pengaruhnya adalah dampak sosio-kultural yang 

diakibatkan oleh Pemekaran Daerah. HR. Makagansa dalam bukunya Tantangan Pemekaran Daerah menyebutkan, bahwa implikasi positif dari pemekaran adalah pengakuan sosial, politik, dan kultural terhadap masayarakat desa. Sebuah entitas masyarakat yang memiliki sejarah kohesivitas panjang dilahirkan kembali daerah lama itu dalam administrasi pemerintahan Indonesia mutakhir, yaitu sebagai daerah otonom dalam sistem pemerintahan Indonesia Modern. Namun pemekaran juga berimplikasi pada terjadinya konflik horizontal dalam masyarakat yang terpecah dalam dua kelompok (pro dan anti pemekaran). Selain itu juga terjadi konflik horizontal antara pemerintah daerah baru dan daerah induk dalam persoalan pengalihan asset maupun batas wilayah. Namun tidak menutup kemungkinan terjadi konflik vertikal antara pemerintah daerah baru dengan masyarakatnya sendiri dalam persoalan tanah yang dibutuhkan pemerintah membangun perkantoran maupun infrastruktur ekonomi lainnya (H. R. Makagansa, 2008 : 29).

Disebutkan terakhir merupakan bahaya laten dalam sebuah DOB baru, bahaya laten dalam arti merupakan sebuah konflik yang sudah pasti terjadi dalam sebuah DOB. Konflik tanah antara pemerintah DOB dengan masyarakat secara kasat mata paling mungkin terjadi dikarenakan oleh meningkatnya harga tanah di DOB tersebut. Karena DOB tersebut lahir menjadi sebuah daerah baru yang juga secara otomatis menjadi wilayah pertumbuhan ekonomi yang baru. Sehingga seiring dengan itu pula harga tanah di wilayah DOB pun meningkat, terutama di wilayah ibukota kabupaten/kota DOB tersebut. Kesimpulan sementara ini memang merupakan kenyataan yang tidak dapat dihindarkan, sehingga niatan dari setiap orang/pemilik tanah kemudian melakukan privatisasi terhadap lahanlahan miliknya, maka pada akhirnya tidak terhindar pula dari gesekangesekan kepentingan dengan latar ekonomi atas tanah tersebut.

Persoalan privatisasi yang kemudian menimbulkan konflik ini memang kejadian nyata yang sudah terjadi berabad-abad lalu sejak masyarakat Eropa mulai melakukan privatisasi atas lahan akibat pertumbuhan ekonomi pasca berakhirnya Abad Kegelapan Eropa. Privatisasi yang kemudian menghilangkan apa yang disebut common atau lahan/lapangan yang menjadi milik umum. Oleh karena itu melihat dari kenyataan tersebut, membuktikan bahwa privatisasi yang diakibatkan oleh meningkatnya harga tanah telah dibuktikan menjadi penyebab konlflik sosial. Begitu pun lahirnya DOB telah memicu terjadinya privatisasi akibat meningkatnya harga tanah, sehingga konflik tanah di DOB tergolong tinggi akibatnya bertumbuhnya sebuah wilayah menjadi pusat perekonomian, politik, sosial budaya yang baru.

Tujuan

sesungguhnya

pembentukan DOB adalah untuk memicu pertumbuhan ekonomi di daerah. Sehingga kemudian dapat memicu pertumbuhan ekonomi nasional. Maka tidaklah heran jika berhasil tidaknya otonomi daerah di Indonesia selalu dilihat dari berapa besar PAD daerah, dan pertumbuhan 

ekonomi di daerah. Sementara itu untuk mewujudkan pertumbuhan ekonomi DOB salah satu unsur pendukung utamanya adalah tersedianya sarana infrastruktur. Sehingga baik itu pelayanan administrasi, sarana pendukung pengambil kebijakan, sarana distribusi, dan infrastruktur lainnya yang mampu mendukung terwujudnya pertumbuhan ekonomi. Oleh karena itu pemerintah DOB sangat membutuhkan lahan untuk dibangunnya infrastruktur pendukung tersebut. Maka dilakukannya pengadaan lahan, atau memanfaatkan lahan yang telah dimiliki oleh negara yang tentunya telah menjadi milik DOB pasca pemekaran. Namun bukan tidak mungkin proses tersebut kemudian memunculkan konflik antara pemerintah dengan masyarakat, diakibatkan masyarakat yang sedang bertumbuh tersebut mengalami apa yang disebut sebagai private syndrome.

\section{Rumusan Masalah}

Harapan bahwa dengan dibentuknya DOB mampu mendekatkan pelayanan administrasi, mempercepat pertumbuhan ekonomi, memicu pembangunan di daerah, dan sebagai wujud demokratisasi di tingkat daerah. Berbagai tujuan ini menjadi mustahil diwujudkan jika DOB yang baru dibentuk selalu diiring dengan berbagai persoalan terutama persoalan keruangan dan aset daerah. Persoalan keruangan berkaitan dengan ketersediaan lahan bagi pembangunan infrastruktur fisik penunjang pemerintahan DOB. Transfer aset dari daerah induk juga selalu menimbulkan permasalahan, karena tidak didasarkan pada asa keadilan dan keseimbangan berdasarkan kebutuhan DOB. \begin{tabular}{lrr}
\multicolumn{1}{c}{ Fakta } & hasil & penelitian \\
perkembangan & kota di & Indonesia \\
menunjukkan & bahwa seiring & dengan \\
terjadinya & peningkatan & kegiatan \\
ekonomi, suatu wilayah yang & memiliki \\
karakteristik & pedesaan & akan
\end{tabular} berkembang secara alamiah ke arah karakteristik perkotaan (RP. Tambunan, 2004). Kabupaten Nagekeo sebagai DOB tentu mengalami perubahan ini, dan akan berimbas pada meningkatnya nilai ekonomis barang atau aset. Tanah sebagai salah satu faktor produksi dalam eknomi, tentu mengalami peningkatan harga yang signifikan tergantung pada potensi wilayah.

Oleh karena itu masalah keruangan dan kebutuhan aset penunjang infrastruktur daerah menjadi isu utama di Kabupaten Nagekeo. Kantor DPRD menjadi salah satu infrastruktr fisik yang dibutuhkan oleh sebuah DOB seperti Nagekeo. Oleh karena itu pengadaannya menjadi sangat penting, demi menunjang jalannya pemerintahan di Nagekeo. Namun proses pembangunan kantor DPRD yang dimulai dari pengadaan tanah, ganti rugi, hingga pembangunan fisik ternyata menimbulkan persoalan berlarut selama bertahun-tahun sejak awal pembentukan Nagekeo sebagai DOB.

Selain karena faktor proses pengadaan yang tidak sesuasi prosedur hingga tingginya nilai ekeonomis tanah di lokasi pembangunan, namun proses pembangunan yang dilatari oleh berbagai kepentingan individu maupun kelompok tent menjadi pemicu munculnya konflik yang berkepanjangan ini. Oleh karena itu penelitian ini bertujuan untuk mendeskripsikan konflik tanah 

Pembangunan Kantor DPRD Nagekeo yang terjadi sejak tahun 2007 hingga tahun 2014. Namun hasil penelitian ini akan sangat ditentukan oleh putusan pengadilan terkait kasus dugaan $\mathrm{KKN}$ dalam konflik pembangunan kantor DPRD Nagekeo. Sementara mengenai konflik kepemilikan dan proses yang bermasalah telah memiliki keputusan hukum tetap. Sehingga penulis mampu mengambil kesimpulan yang mengeneralisir mengenai konflik tanah di DOB dengan studi kasus Konflik Tanah Pembangunan Kantor DPRD Kabupaten Nagekeo.

\section{Tinjauan Pustaka}

\section{Konflik Tanah}

Konflik tanah adalah proses interaksi antara dua orang atau lebih atau kelompok yang masing-masing memperjuangkan kepentingannya atau objek yang sama, yaitu tanah dan benda-benda lain yang berkaitan dengan tanah. Secara umum ada beberapa macam sifat permasalahan dari suatu konflik tanah antara lain, (1) masalah yang menyangkut prioritas dapat ditetapkan sebagai pemegang hak yang sah atas tanah yang berstatus hak atau atas tanah yang belum ada haknya, (2) bantahan terhadap sesuatu alasan hak atau bukti perolehan yang digunakan sebagai dasar pemberian hak, (3) kekeliruan atau kesalahan pemberian hak yang disebabkan penerapan peraturan yang kurang atau tidak benar, (4) konflik atau masalah lain yang mengandung aspek-aspek sosial (Urip Santoso. 2005; 23).

\section{Potensi Konflik Tanah Pada Era}

\section{Otonomi Daerah}

Makna mengelola daerah sendiri berdasarkan potensi daerah yang menjadi bagian dari fokus otonomi daerah ternyata dalam penerapannya diartikan secara salah oleh banyak elit lokal dan pemerintah daerah. Otonomi Daerah yang diterapkan ternyata dianggap seolah daerah melepaskan diri dari cengkeraman pemerintah pusat. Salah satu kesalahan pengertian ini dapat dilihat dari interpretasi mereka terhadap Pasal 11 ayat (2) yang menyatakan "Bidang pemerintahan yang wajib dilaksanakan oleh daerah Kabupaten/Kota meliputi pekerjaan umum, kesehatan, pendidikan, dan kebudayaan; pertanian, perhubungan, industri dan perdagangan, penanaman modal, lingkungan hidup, pertanahan, koperasi, dan tenaga kerja". Pasal ini diinterpretasikan sebagai pemeberian wewenang sepenuhnya kepada daerah untuk menguasai sektor-sektor sosial yang disebutkan. Padahal kita tahu bahwa sebuah UU tidak secara otomatis menghilangkan wewenang UU sektoral lainnya, yang mungkin saja di dalamnya masih mengakui wewenang pemerintah pusat. Sebuah UU hanya membatalkan UU sejenis yang dijadikan revisi, tidak membatalkan UU sektoral lain. Sehingga tingkatannya adalah UU No. 32 Tahun 2004 hanya membatalkan UU No. 22 Tahun 1999 dan UU No. 22 Tahun 1999 hanya bisa membatalkan UU No. 5 Tahun 1974 dan UU No. 5 Tahun 1979.

Kebijakan pertanahan Orde Baru yang kapitalistik memang sangat mengedepankan aspek normatif hukum positif dan mengabaikan aspek kearifan 

lokal dalam penguasaan dan kepemilikan tanah. Sehingga ketika reformasi 1998 masyarakat adat dan masyarakat umum lainnya yang menjadi korban praktek kapitalistik Orde Baru seolah mendapatkan "angin segar" untuk meraih kembali hakhaknya atas tanah, konflik agraria pun tak terhindarkan. Untuk meredam konflik awal reformasi ini MPR mengeluarkan TAP MPR No. IX/MPR/2001 yang memerintahkan kepada DPR dan Presiden untuk segera mengganti UU No. 5 Tahun 1960. UU pengganti tersebut harus memuat desentralisasi di bidang keagrariaran. Namun UU pengganti yang dimaksud tidak segera terealisasikan, ditambah lagi dengan adanya amandemen UUD membuat kekuatan paksa DPR menjadi melemah. Terlebih lagi dengan dikeluarkannya UU No. 10 tahun 2004 tentang Pedoman Penyusunan Peraturan Perundang-undangan, yang tidak lagi memasukkan Ketetapan MPR dalam tata urutan perundang-undangan, karena dianggap sebagai produk politis, bukan produk hukum (Soetandyo Wignosubroto, 2005:181).

Hak DOB atas pertanahan kemudian dipertegas lagi dengan adanya Keppres RI No. 34 Tahun 2003 tentang Kebijakan Nasional di Bidang Pertanahan, dalam Pasal 2 sebagai bentuk tugas perbantuan. Peraturan Presiden No. 36 Tahun 2005 Tentang Pengadaan Tanah bagi Pelaksanaan Pembangunan Untuk Kepentingan Umum. Substansi, atau materi yang diatur dalam Peraturan Presiden juga turut menimbulkan masalah lain. PP 36 Tahun 2005 ini memberikan hak bagi pemerintah untuk melakukan pencabutan hak atas tanah, bangunan, tanaman, serta benda-benda lain yang berkaitan dengan tanah oleh negara dengan pemberian ganti rugi senilai Nilai Jual Objek Pajak (NJOP), berdasarkan perhitungan dari instansi pemerintah yang bertujuan bagi pembangunan infrastruktur maupun sarana prasarana kepentingan umum.

Sehingga hak masyarakat atas tanah, bangunan, tanaman, serta bendabenda lain yang berkaitan dengan tanah menjadi terganggu. Terlebih yang dimaksud dengan kepentingan umum dalam Peraturan Presiden No. 36 Tahun 2005 tersebut telah mengalami perluasan. PP ini dianggap oleh sebagian besar akademisi telah memperlemah akses masyarakat terhadap haknya atas tanah dan dilanggarnya hak sipil politik dan hak ekonomi, sosial, budaya masyarakat oleh pemerintah. PP No. 36 Tahun 2005 ini kemudian direvisi dengan kemunculan Perpres No. 65 Tahun 2006 tentang Perubahan Atas PP No. 36 Tahun 2005 tentang Pengadaan Tanah bagi Pelaksanaan Untuk Kepentingan Umum. Hal ini membuktikan bahwa PP No. 36 Tahun 2005 tidak responsif dan tidak mampu mengakomodir kepentingan dan aspirasi masyarakat Indonesia dalam bidang pertanahan. Pada akhirnya regulasi yang berubah serta ketidakjelasan persoalan agraria turut menjadi faktor dalam berpotensinya muncul konflik pertanahan di DOB.

\section{A. Metode Penelitian}

Penelitian dalam karya ilmiah ini menggunakan metodologi penelitian kualitatif dengan pendekatan deskripsi analitis, dengan proses pengumpulan data menggunakan teknik wawancara 

dan studi kepustakaan. Tujuan penelitian ini yaitu menggambarkan konflik tanah di DOB antara pemerintah daerah dengan masyarakat, yaitu dengan studi kasus konflik tanah pembangunan kantor DPRD Kabupaten Nagekeo, Provinsi Nusa Tenggara Timur. Penelitian ini dilakukan pada tahun 2014. Nagekeo adalah DOB pada tahun 2007 dari kabupaten induk yaitu kabupaten Ngada. Konflik Tanah Pembangunan Kantor DPRD Nagekeo merupakan konflik tanah yang terjadi sejak awal pemekaran hingga tahun 2014 masih belum terselesaikan. Proses litigasi konflik ini berlangsung hingga banding ke MA, dan PK terakhir tahun 2014. Namun proses eksekusi vonis pengadilan hingga tulisan ini dibuat belum dilaksanakan sama sekali.

\section{Hasil Penelitian dan Pembahasan}

\section{Sejarah Dan Pertumbuhan Ekonomi Di Nagekeo}

Kabupaten Nagekeo adalah salah satu kabupaten di Provinsi Nusa Tenggara Timur, tepatnya berada di salah satu pulau terbesar di provinsi ini yaitu pulau Flores. Nagekeo berada di tengah-tengah pulau Flores diapit oleh 3 kabupaten di bagian timur, dan 4 kabupaten lainnya di bagian barat. Kabupaten Nagekeo dimekarkan pada tahun 2007 dengan ibukota Mbay, kecamatan Aesesa. Bagian utara berbatasan dengan Laut Flores, bagian selatan berbatasan dengan laut Sawu, bagian timur berbatasan dengan Kabupaten Ende dan bagian barat berbatasan dengan Kabupaten Ngada.

Jika dilihat dari data tabel 1, Kecamatan Aesesa yang menjadi lokasi dimana ibukota Kabupaten Nagekeo berada memiliki luas wilayah yang terluas dibandingkan dengan Kecamatan lainnya.

Tabel 1. Luas Wilayah Kabupaten Nagekeo Berdasarkan Kecamatan

$\begin{array}{llll}\text { No } & \text { Kecamatan } & \begin{array}{l}\text { Luas } \\ \left(\mathrm{Km}^{2}\right)\end{array} & \begin{array}{l}\text { Persentase } \\ (\%)\end{array} \\ 1 & \text { Mauponggo } & 102,52 & 7,24 \\ 2 & \text { Keo Tengah } & 65,62 & 4,63 \\ 3 & \text { Nangaroro } & 238,02 & 16,80 \\ 4 & \text { Boawae } & 325,42 & 22,97 \\ 5 & \text { Aesesa } & 71,00 & 5,01 \\ & \text { Selatan } & 432,29 & 30,51 \\ 6 & \text { Aesesa } & 182,09 & 12,85 \\ 7 & \text { Wolowae } & 1416,99 & 100\end{array}$

Tabel 2. Luas Lahan Sawah dan Lahan Kering Potensial di Kabupaten Nagekeo Menurut Kecamatan Tahun 2007

\begin{tabular}{|c|c|c|c|c|}
\hline \multirow[t]{2}{*}{ No } & Kecamatan & Lahan & Lahan & \multirow[t]{2}{*}{ Jumlah } \\
\hline & & Sawah & Kering & \\
\hline 1 & Mauponggo & 1,307 & 8,945 & \multirow{3}{*}{$\begin{array}{l}10,525 \\
6,562\end{array}$} \\
\hline \multirow[t]{2}{*}{2} & Keo & & & \\
\hline & Tengah & 255 & 7,24 & \\
\hline 3 & Nangaroro & 200 & 23,602 & 23,802 \\
\hline 4 & Boawae & 4,265 & 28,277 & 32,542 \\
\hline 5 & Aesesa & 4,632 & 38,597 & 43,229 \\
\hline \multirow[t]{2}{*}{6} & Aesesa & 25 & 7075 & \multirow[t]{2}{*}{7,100} \\
\hline & Selatan & 25 & $1,0 / 5$ & \\
\hline \multirow[t]{3}{*}{7} & Wolowae & 564 & 17,644 & 18,209 \\
\hline & NAGEKEO & 11,249 & 130,447 & 141,696 \\
\hline & Presentase & 7.94 & 92,06 & 100,00 \\
\hline
\end{tabular}

Kecamatan Aesesa sebagai ibukota Kabupaten Nagekeo juga merupakan daerah dengan wilayah atau lahan yang paling banyak terjadi konflik tanah, baik antara masyarakat dengan masyarakat maupun masyarakat dengan pemerintah.

Dari tabel 2 dapat dilihat pula bahwa lahan kering di Kabupaten 

Nagekeo lebih tinggi presentasinya dibandingkan lahan sawah, sehingga dapat dilihat bahwa lahan perkebunan selain sawah merupakan pekerjaan utama masyarakat Nagekeo.

Melihat jumlah penduduk per Kecamatan dan rata-rata pertumbuhan penduduk dapat membantu kita untuk memahami jumlah kepadatan penduduk yang kemudian berpotensi menjadi penyebab konflik tanah.

Tabel 3. Luas Wilayah Menurut Kecamatan Tahun 2013

\begin{tabular}{llll} 
No & Kecamatan & $\begin{array}{l}\text { Luas } \\
\mathrm{km}^{2}\end{array}$ & $\%$ \\
1 & Mauponggo & 102,52 & 7,24 \\
2 & Keo Tengah & 65,62 & 4,63 \\
3 & Nangaroro & 238,02 & 16,80 \\
4 & Boawae & 325,42 & 22,97 \\
5 & Aesesa & 71,00 & 5,01 \\
& Selatan & 432,29 & 30,51 \\
6 & Aesesa & 182,091 & 12,85 \\
7 & Wolowae & 416,96 & 100,00 \\
\multicolumn{4}{l}{ Sumber : Registrasi Penduduk 2013 }
\end{tabular}

Tabel 4. Jumlah dan Kepadatan Penduduk Menurut Kecamatan Tahun 2013

\begin{tabular}{|c|c|c|c|c|}
\hline \multirow{2}{*}{\multicolumn{2}{|c|}{ Kecamatan }} & \multicolumn{2}{|c|}{ Penduduk } & Kepadatan \\
\hline & & Jumlah & $\%$ & $\begin{array}{l}\text { Penduduk } \\
\text { (orang/ } \\
\mathrm{km}^{2} \text { ) }\end{array}$ \\
\hline 1 & Mauponggo & 23173 & 16,17 & 226 \\
\hline 2 & $\begin{array}{l}\text { Keo } \\
\text { Tengah }\end{array}$ & 13851 & 9,66 & 211 \\
\hline 3 & Nangaroro & 19923 & 13,90 & 83 \\
\hline 4 & Boawae & 36347 & 25,36 & 111 \\
\hline 5 & $\begin{array}{l}\text { Aesesa } \\
\text { Selatan }\end{array}$ & 8055 & 5,62 & 113 \\
\hline 6 & Aesesa & 36885 & 25,74 & 85 \\
\hline 7 & Wolowae & 5080 & 3,54 & 27 \\
\hline & NAGEKEO & 143314 & 100,00 & 101 \\
\hline
\end{tabular}

Jika dilihat dalam tabel jumlah penduduk tertinggi ada di Kecamatan Aesesa yang juga merupakan lokasi ibukota Kabupaten Nagekeo yang jumlah penduduknya 36.885 jiwa atau sebesar 25,74 dari jumlah penduduk Nagekeo. Hal ini cukup timpang jika dibandingkan dengan jumlah penduduk di Kecamatan lain, dan kepadatan jumlah penduduk sendiri di Kecamatan Aesesa sendiri $85 \mathrm{jiwa} / \mathrm{Km}$. Tentu hal ini tidak mengherankan jika kita lihat bahwa pusat kegiatan politik dan ekonomi ada pada satu tempat yang kemudian secara langsung memicu terjadinya perpindahan penduduk baik secara massif maupun pertahap ke tempat yang menjadi pusat politik dan ekonomi tersebut dan berpengaruh terhadap potensi konflik tanah di Kecamatan Aesesa merupakan yang paling tinggi.

Sedikit mengulik sejarah pembentukan administratif Nagekeo bermula dari dikeluarkannya UU No. 64 tahun 1958 tentang Provinsi Nusa Tenggara yang dipecah menjadi Daerah Swatantra Tingkat I Bali, Nusa Tenggara Barat dan Nusa Tenggara

Timur. Daerah Tingkat I NTT meliputi daerah Flores, Sumba dan Timor. Melalui UU No. 69/1958 tentang pembentukan daerah-daerah tingkat II dalam wilayah daerah tingkat I Bali, Nusa Tenggara Barat dan Nusa Tenggara Timur, maka daerah swatantra NTT dibagi menjadi 12 daerah Swatantra Tingkat II yaitu: Sumba Barat, Sumba Timur, Manggarai, Ngada, Ende, Sikka, Flores Timur, Alor, Kupang, Timor Tengah Selatan, Timor Tengah Utara dan Belu (Arsip Nasional Sejarah Nasional Provinsi Nusa Tenggara Timur). 

Pembentukan kecamatan pada masing-masing kabupaten di Provinsi Nusa Tenggara Timur ditetapkan pada tanggal 28 Februari 1962. Melalui Surat Keputusan Gubernur Kdh. Tk I NTT No. Pem. 66/1/2 tentang pembentukan 64 kecamatan dalam Provinsi Nusa Tenggara Timur. Kabupaten Ngada mencakup 6 Kecamatan, yaitu: Ngadha Utara, Ngadha Selatan, Nage Utara, Nage Tangah, Keo dan Kecamatan Riung. Pada tahun 1963 dikeluarkan Keputusan Gubernur Kepala Drh. Tk. I NTT No. Pem. 66/ I/2 Tanggal 20 Mei 1963 tentang pemekaran Kecamatan Keo menjadi Kecamatan Mauponggo (yang merupakan wilayah Keo Barat) dan Kecamatan Nangaroro (yang merupakan wilayah Keo Timur). Melalui keputusan tersebut, Nama Kecamatan di Kabupaten Ngada diubah sebagai berikut: Kecamatan Ngada Utara menjadi Kecamatan Bajawa; Kecamatan Ngadha Selatan menjadi Kecamatan Aimere; Kecamatan Nage Tengah menjadi Kecamatan Boawae; Kecamatan Nage Utara menjadi Kecamatan Aesesa; Kecamatan Keo menjadi Kecamatan Mauponggo dan Kecamatan Nangaroro(Arsip Nasional Sejarah Nasional Provinsi Nusa Tenggara Timur).

Pertengahan dekade 1990-2000, agenda pemindahan ibukota Kabupaten Ngada dari Bajawa ke Mbay, mencapai puncaknya dengan diterbitkannya Peraturan Pemerintah No. 65 Tahun 1996, yang menetapkan Ibukota Kabupaten Ngada yang baru yaitu Mbay. Ide dan gagasan tersebut menjadi kekuatan dengan sebelumnya (1994) Mbay ditetapkan sebagai Kawasan Pengembangan Ekonomi Terpadu (Kapet). Pergantian kepemimpinan
Kepala Daerah (Bupati) Ngada pada tahun 2000 dari Drs. Johanes S. Aoh (berasal dari Nagekeo) ke Ir. Albertus Nong Botha (berasal dari Ngada, Kabupaten Induk), mengakibatkan dua agenda besar yaitu pemanfaatan kebijakan nasional Kapet Mbay dan pemindahan ibukota Kabupaten Ngada ke Mbay, mengalami masa pasang surut.

Masa pasang surut tersebut, yang secara substansif menjadi argumen dan latar belakang lahirnya gagasan perjuangan pembentukan Kabupaten Nagekeo sebagai pemekaran Kabupaten Ngada. Pada tahun 2002, Kabupaten Ngada telah mencakup 14 wilayah kecamatan yaitu: Aimere, Ngada Bawa, Bajawa, Golewa, Jerebu'u, So'a, Riung, Riung Barat, Aesesa, Nangaroro, Boawae, Mauponggo, Wolowae, dan Keo Tengah. Bertepatan dengan peresmian Nagekeo sebagai suatu daerah otonom baru (Kabupaten) setelah DPR telah menyetujui Rancangan Undang-Undangnya pada 8 Desember 2006. Kabupaten Nagekeo adalah 1 dari 16 kabupaten/kota baru yang dimekarkan pada 2006. Dengan dasar Undang-Undang No. 2 Tahun 2007, yang ditetapkan pada tanggal 22 Mei 2007 tentang Pembentukan Kabupaten Nagekeo sebagai daerah otonom lingkup wilayahnya, mencakup 7 kecamatan yaitu: Aesesa, Aesesa Selatan, Nangaroro, Boawae, Mauponggo, Wolowae, dan Keo Tengah. Sedangkan ibukota bertempat di Mbay, Kecamatan Aesesa.

PP No. 65 Tahun 1996 yang ingin memindahkan ibukota kabupaten Ngada dari Bajawa ke Mbay, secara implisit telah menjadikan Mbay sebagai daerah 

pertumbuhan ekonomi yang baru selain ibukota Bajawa. Hal ini terlihat dari dibentuknya wilayah transmigrasi di Mbay, sehingga dimungkinan adanya transmigran lokal dari kecamatan lain di Kabupaten Ngada ke Kecamatan Aesesa. Selanjutnya Mbay ditetapkan sebagai Kawasan Pengembangan Ekonomi Terpadu (KAPET) semakin memperkuat posisi Mbay dan Kecamatan Aesesa sebagai wilayah pertumbuhan ekonomi baru. Proses transmigrasi dan penetapan sebagai Kawasan Pengembangan Ekonomi oleh pemerintah pusat, berdampak langsung pada politik keruangan di Mbay. Selanjutnya hal ini berdampak pula pada harga tanah, dan persoalan kepemilikan lahan di Mbay.

\section{Konflik Tanah Di DOB: Konflik Tanah Pembangunan Kantor DPRD Nagekeo}

Konflik tanah pembangunan kantor DPRD Kabupaten Nagekeo dimulai sejak Tahun 2008, 1 Tahun setelah pemekaran Kabupaten Nagekeo. Pada Tahun 2008 bulan April Kabupaten Nagekeo masih dipimpin oleh seorang penjabat sementara yaitu Drs. Elias Djo, dengan ketua DPRD sementara saat itu Paulinus Nuwa Veto, karena pemilukada pertama Kabupaten Nagekeo diadakan pada bulan Agustus 2008 sehingga saat itu pemerintahan daerah Kabupaten Nagekeo hanya bersifat sebagai pemerintahan administratif atau lebih tepatnya pemerintahan transisi. Sehingga pemerintahan saat itu bertujuan untuk mempersiapkan segala sesuatu baik yang berkaitan dengan administrasi maupun sarana prasarana infrastruktur bagi pemerintahan baru Kabupaten
Nagekeo dalam pelayanan publik. Berdasarkan alasan tersebut maka pemerintahan transisi inipun mempersiapkan lahan bagi pembangunan kantor-kantor pemerintahan di ibukota Nagekeo, Mbay. Salah satunya adalah pembangunan kantor DPRD yang akan dibangun dalam satu lokasi dengan kantor pemerintahan lainnya yaitu di lokasi bernama Pomamela, Kelurahan Lape, Kecamatan Aesesa. Pengadaan tanah bagi pembangunan kantor DPRD Nagekeo ini selanjutnya menimbulkan konflik berkepanjangan antara Pemda Nagekeo dengan masyarakat adat suku Lape.

\section{a. Kronologis Konflik}

Pada tanggal 21 Juni 2007 tanah di sebelah barat dari kantor Bupati seluas 1.5 ha di wilayah Pomamela, Kelurahan Lape, Kecamatan Aesesa telah diserahkan oleh para ketua Suku Lape kepada Konradus Ru Remi. Pada bulan januari 2008, pemerintah mengirim surat kepada suku Lape meminta lahan tersebut (yang telah menjadi milik Konradus $\mathrm{Ru}$ Remi). Surat bernomor Pada bulan januari 130. 01/T.IPraja/02/01/2008, ditandatangani penjabat bupati saat itu, Drs. Elias Djo. Namun surat ini tidak dijawab oleh suku Lape, dan tidak ada keputusan apapun dari suku Lape mengenai permohonan tersebut. Namun pada tanggal 28 April 2008 Efraim Fao menyerahkan lahan tersebut (yang diminta oleh Pemda Nagekeo ke suku Lape) kepada Pemerintah Kabupaten Nagekeo dengan mengklaim dirinya sebagai pemilik sah lahan tersebut. Proses ini terdapatnya ganti rugi lahan dengan total nilai sebesar Rp 750 Juta 

kepada Efraim Fao (BAP PN Bajawa bernomor 144/Pdt. 6/2012/PN).

Berdasarkan penyerahan yang dilakukan oleh Efraim Fao tersebut Pemda Nagekeo awal bulan Mei 2008 memulai lakukan pembangunan berupa penggusuran lahan oleh $\mathrm{CV}$. Victori selaku kontraktor pembangunan Kantor DPRD Nagekeo. Menyadari kegiatan pembangunan tersebut, Konradus $\mathrm{Ru}$ Remi dan suku Lape melakukan protes kepada pemerintah Nagekeo karena menganggap lahan milik mereka diserobot oleh Efraim Fao, dan Pemda Nagekeo. Pemda Nagekeo bersedia melakukan mediasi dengan Konradus $\mathrm{Ru}$ Remi dan suku Lape pada Juni 2008. Mediasi tersebut tidak menghasilkan keputusan, sehingga Konradus $\mathrm{Ru}$ Remi dan suku Lape melakukan gugatan ke PN Bajawa. Pada 17 Februari 2009 merupakan sidang gugatan pertama terhadap kasus ini dengan penggugat Konradus $\mathrm{Ru}$ Remi mewakili Suku Lape, dengan tergugat 1 Efraim Fao, tergugat 2 Pemda Nagekeo, tergugat 3 DPRD Nagekeo (BAP PN Bajawa bernomor 144/Pdt. 6/2012/PN).

Gugatan Konradus Ru Remi dan suku Lape ini kemudian mengalami banding hingga ke tingkat kasasi oleh Pemda Nagekeo yang dalam berbagai vonis di tingkat PN, PT, maupunPTUN Surabaya dianggap benar melakukan kesalahan berupa penyerobotan tanah dan perampasan hak atas tanah. Pada tanggal 11 Agustus 2011 MA melakukan PK dan mmberikan vonis yang sama dengan vonis pengadilan di tingkat bawah. Sehingga Pemda Nagekeo secara legalitas hukum dianggap telah melakukan kesalahan dalam pengadaan tanah bagi kepentingan umum dengan tuduhan kesalahan berupa penyerobotan lahan milik masyarakat (Tesis Fransiskus X. Gian Tue Mali, 2015 : 91-125).

\section{b. Analisis Kronologi Konflik}

Jika disingkat Faktor Awal konflik tanah maka dapat dilihat bahwa sejak awal pemerintah mengakui hak suku Lape, terbukti dengan Penjabat Bupati Nagekeo, Elias Djo, pada Tahun 2008 yang mengirim surat yang meminta lahan seluas 2.5 ha kepada Suku Lape yang berlokasi di Pomamela, namun surat tersebut belum dibalas oleh Suku Lape pemerintah Nagekeo melakukan pembicaraan dan mengadakan proses penyerahan lahan tersebut dengan penyerah tanah atas nama Efraim Fao. Efraim Fao mengklaim lahan yang diminta oleh pemerintah adalah miliknya bukanlah milik Suku Lape. Pemda Nagekeo malah menerima Efraim Fao sebagai pemilik lahan tersebut. Selain itu Pemda Nagekeo dalam proses penyerahan di tahun 2008, suku Lape diminta menandatangani surat pernyerahan oleh Efraim Fao sebagai saksi demi mengesahkan proses penyerahan tersebut, namun ditolak oleh suku Lape. Hal ini menunjukkan bahwa pada hakikatnya Pemda Nagekeo menyadari betul hak kepemilikan suku Lape atas tanah tersebut.

Selain dilakukannya gugatan atas klaim Efraim Fao atas tanah tersebut, suku Lape juga menolak status Efraim Fao sebagai bagian dari anggota Suku Lape. Bagi Suku Lape, leluhur Efraim Fao adalah orang Suku Lidhe yang datang dan diberikan tanah oleh Suku Lape di Pomamela. Namun sejak 

ayahnya meninggal Efraim Fao tidak lagi melakukan pengelolahan atas lahan tersebut, sehingga berdasarkan aturan Suku lahan tersebut kembali menjadi milik Suku Lape. Karena hak yang diberikan kepada leluhur Efraim Fao adalah hak pakai bukan hak milik (Hasil Wawancara Ketua LPA Lape, Philipus F. Libha. Tanggal 12 Oktober 2014). Penolakan inipun diakui oleh Efraim Fao bahwa dirinya bukanlah bagian dari suku Lape.

Pertentangan antara suku Lape dengan Efraim Fao tentang hak milik atas tanah, dan status warga adat yang tidak diakui menunjukkan terdapatnya permasalahan internal di dalam suku. Singkatnya ketidakjelasan pembagian lahan sejak masa lalu kemudian menjadi masalah di masa depan. Sehingga bagi Pemda Nagekeo konflik ini adalah konflik internal Suku Lape, sedangkan pemerintah berada pada posisi sebagai penerima lahan. Penyangkalan pun muncul dari Bagian Administrasi Sekda Nagekeo yang menolak jika pemda sebagai penyebab konflik, karena ketidaktahuan pemda siapa pemilik sah tanah tersebut, sehingga jika ada masyarakat yang datang menyerahkan tanah, pemda sifatnya hanya menerima saja (Hasil Wawancara Elias Djo, Bupati Nagekeo, Tanggal 17 Oktober 2014).

\section{Analisis Pelanggaran Regulasi Konflik Tanah Pembangunan Kantor DPRD Nagekeo}

Berbagai kronologis dan faktor awal konflik tanah ini kemudian menunjukkan terdapatnya beberapa pelanggaran yang dilakukan oleh Pemda Nagekeo. Karena dari keseluruhan proses tersebut dan dalam pembuktian di PN Bajawa dapat dilihat bahwa Pemda Nagekeo dalam proses pengadaan tanah bagi pembangunan kantor DPRD Nagekeo tidak memenuhi persyaratan dalam prosedur Pengadaan Tanah Bagi Kepentingan Umum sebagaimana yang termuat dalam Perpres RI No. 36 Tahun 2005 maupun Perpres No. 65 Tahun 2006, tentang diharuskan adanya Panitia Pengadaan Tanah Bagi Kepentingan Umum. Meskipun kemudian Perpres tersebut diubah dalam Perpres RI No. 40 Tahun 2014 Tentang Perubahan Atas Perpres No. 71 Tahun 2012 Tentang Penyelenggaraan Pengadaan Tanah Bagi Kepentingan Umum Pasal 121 yang menyatakan bahwa pengadaan tanah dibawah 5 Ha dapat dilakukan secara langsung oleh instansi terkait baik melalui jual beli maupun tukar menukar atau cara lain berdasarkan kesepakatan kedua belah pihak.

Namun karena proses ini terjadi pada Tahun 2008 sebelum Perpres tersebut diadakan oleh presiden saat itu. Maka sudah selayaknya Pemda Nagekeo membentuk Panitia Pengadaan Tanah, yang tugasnya tertuang dalam Peraturan Kepala BPN No. 3 Tahun 2007 dan Perpres No. 65 Tahun 2006. Secara umum tugasnya antara lain mengadakan penelitian dan inventarisasi lahan, penelitian status hukum tanah maupun pemiliknya, penentuan besarnya ganti rugi, sosialisasi kepada masyarakat sekitar, musyawarah dengan para pemegang hak atas tanah, dan menyelenggarakan pelaksanaan penyerahan serta proses administrasi dan perwujudan ganti rugi nilai tanah Pasal 7 Perpres Nomor 65 Tahun 2006). 

Selain berbagai pelanggaran diatas, jika didasarkan pada Perpres No. 71 Tahun 2012 tentang Pengadaan Tanah Bagi Pembangunan Untuk Kepentingan Umum Pasal 1 angka 2 menyatakan bahwa "Pengadaan tanah adalah kegiatan menyediakan tanah dengan cara memberikan ganti kerugian yang layak dan adil kepada Pihak yang berhak". Pemda Nagekeo dapat dianggap samasekali tidak melakukan ganti rugi lahan terhadap pemegang hak atas tanah. Berbagai proses inilah yang tidak terlaksana dalam pengadaan tanah bagi pembangunan kantor DPRD Nagekeo.

Selain itu jika berkaca pada UU No. 2 Tahun 2012 tentang Pengadaan Tanah Bagi Pembangunan Untuk Kepentingan Umum, terdapat mekanisme yang hampir sama dengan Perpres-Perpres diatas. Aspek substansial dari UU No. 2 Tahun 2012 diantaranya yaitu prinsip dasar pengadaan tanah adalah musyawarah, Keterlibatan masyarakat dalam setiap tahapan dijamin keberadaannya, Penentuan lokasi pembangunan didasarkan atas kesepakatan masyarakat pemilik tanah, dan Objek dan Subjek pengadaan tanah ada kepastian hukum yang jelas. Tetapi melihat keseluruhan proses pengadaan tanah oleh pemerintah Nagekeo untuk pembangunan kantor DPRD Nagekeo tersebut, kesemua aspek substansi tersebut sama sekali tidak terpenuhi.

Dinyatakan dalam persidangan bahwa Pemda Nagekeo telah melakukan negoisasi dengan Tokoh Masyarakat Lape dalam proses pengadaan tanah, hal ini kemudian menjadi pertanyaan adalah, tanah tersebut adalah tanah yang masuk wilayah Suku namun negoisasi dilakukan dengan tokoh masyarakat Lape, sedangkan Suku Lape sendiri adalah Suku yang masih eksis dengan keberadaan Lembaga Pemangku Adat Suku Lape yang sudah berdiri sejak Tahun 1957. Bantahan tentang adanya negoisasi pun muncul dari Ketua Lembaga Pemaku Adat (LPA) Suku Lape (Hasil Wawancara Ketua LPA Lape, Philipus F. Libha. Tanggal 12 Oktober 2014). Terdapat perbedaan antara tokoh masyarakat dan ketua Suku, tokoh masyarakat bisa saja adalah pejabat publik, tokoh agama, ketua komunitas dan sebagainya, sedangkan ketua Suku menurut Kamus Besar Bahasa Indonesia adalah orang yg menjadi pemimpin (raja) suatu Suku yang jabatannya didapat secara turun temurun atau berdasarkan tradisi yang berlaku dalam Suku (Kamus Besar Bahasa Indonesia).

Sedangkan dalam pengakuan di pengadilan saksi Pemda Nagekeo yaitu, Aleks Jata yang saat itu menjabat sebagai camat Aesesa menyatakan bahwa sebelum proses penyerahan tanah di bulan April 2008 telah diadakan negoisasi dengan tokoh masyarakat Lape namun gagal sehingga dalam negoisasi kedua dilakukan dengan Efraim Fao yang mengaku sebagai pemilik tanah tersebut (Salinan Putusan pengadilan dalam Data Perkara Perdata Nomor 2/PDT. G/2009/PN.BJW). Selain pertanyaan tentang tokoh masyarakat yang mana, serta mengapa bukan dengan ketua Suku Lape padahal tanah tersebut adalah milik Suku Lape, proses negoisasi yang dikatakan oleh saksi Pemda Nagekeo tersebut menunjukkan bahwa Pemda Nagekeo tidak 

mengedepankan proses atau poin penting dalam pengadaan tanah bagi kepentingan umum yaitu, Objek dan Subjek pengadaan tanah ada kepastian hukum yang jelas.

\section{Dugaan KKN Konflik Tanah Pembangunan Kantor DPRD Nagekeo}

Proyek Pembangunan Kantor DPRD Nagekeo ini hakikatnya bernilai Rp 10 Milyar. Pasca keluarnya hasil PK dan keputusan banding yang kemudian ditolak, MA kemudian mengeluarkan keputusannya yang bernomor 522 K/Pdt/2015, menyatakan bahwa secara sah dan benar tanah lokasi pembangunan kantor DPRD Nagekeo yang menjadi sengketa adalah milik Konradus $\mathrm{Ru} \quad$ Remi (www.beritasatu.com, Senin, 15 Agustus 2016 Pukul 19.32 WIB). Sehingga gedung yang telah dibangun harus dirobohkan. Proses pembangunan gedung DPRD Nagekeo hingga penghentiannya akibat gugatan ke pengadilan belum mencapai proses finishing, pembangunan terhenti setidaknya dalam tahap yang baru mencapai $63 \%$. Proyek mangkrak 10 Milyar ini kemudian memunculkan berbagai spekulasi, terutama berbagai dugaan $\mathrm{KKN}$, yang diperkuat dengan berbagai pelanggaran regulasi yang dilakukan oleh Pemda Nagekeo. Dugaan ini semakin kuat karena Drs. Elias Djo pada tahun 2007 dimana proses pengadaan tanah ini dimulai, berstatus sebagai Penjabat Bupati Nagekeo, sementara Ketua DPRD saat itu, Paulinus Nuwa Veto. Keduanya pada pilkada Nagekeo tahun 2013, maju sebagai kandidat bupati dan wakil bupati, dengan komposisi Elias Djo cabup, sementara Paulinus Nuwa Veto sebagai cawabup. Pasangan ini memenangkan pilkada 2013 dan memimpin Nagekeo saat ini.

Hal ini ternyata terlihat ketika pada 26 April 2014 berdasarkan hasil pemeriksaan Kejaksaan Negeri Bajawa terdapat indikasi praktek korupsi dana pembangunan gedung DPRD Nagekeo. Keduanya diduga menerima fee sebesar $10 \%$ (www. sergapntt. com edisi 26 April 2014, diakses pada 12 desember 2014). Hal ini cukup beralasan jika dilihat secara fisik gedung tersebut belum selesai dibangun hingga saat ini karena konflik pengadaan tanah tersebut sedangkan tidak terdapat pertanggungjawaban atas dana pembangunan tersebut. Selain dugaan penerimaan fee yang tidak wajar ini, masalah ganti rugi sebesar Rp 750 juta kepada Efraim Fao juga menjadi sorotan tersendiri. Berdasarkan penyelidikan Kajari Ngada, sebagian dana ganti rugi tersebut menggunakan dana bantuan sosial (Bansos) senilai $\mathrm{Rp}$ 155 juta yang dilakukan secara bertahap. Dana bansos ini dicairkan secara bertahap selama 3 Tahun. Proses pencairan dana dilakukan melalui bagian tata pemerintahan (Tatapem) dan Kesejahteraan Rakyat (Kesra) hingga bagian keuangan Kantor Bupati Nagekeo. Pencairan dana tahap pertama menggunakan anggaran bansos pada tahun 2007 dicairkan sebesar Rp 25 juta, tahap kedua menggunakan anggaran bansos tahun 2008 sebesar Rp 25 juta melalui bagian keuangan, sementara pencairan Rp 55 juta melalui bagian Tata Pemerintahan. Tahap ketiga menggunakan anggaran nomenklatur bantuan perkara tanah melalui bagian keuangan tahun 2009 sebesar Rp 50 juta 

(Suara Pembaruan edisi Selasa, 12 Agustus 2014:30).

Jika melihat tahapan keluarnya anggaran ganti rug yang menggunakan dana bansos Tahun 2007 hingga Tahun 2009 terdapat indikasi keterlibatan pihak lain. Karena pada Tahun 2008 terjadi Pilkada dan Johanis S. Aoh menjadi Bupati Nagekeo menggantikan Penjabat Bupati Elias Djo, hingga tahun 2013, berarti Johanis S. Aoh mengetahui adanya aliran dana tersebut. Karena sebagai seorang bupati, tidak mungkin tidak mengetahui adanya aliran dana bansos untuk keperluan lain yang tidak berkaitan dengan bantuan sosial. Hingga saat ini baik Pnenjabat bupati dan ketua DPRD 2007-2008 serta bupati 2008-2013 telah ditetapkan sebagai saksi. Hasil penyelidikan dan peningkatan status akan dilakukan seiring hasil audit BPK Pusat.

Jika dilihat dari keseluruhan proses pengadaan tanah bagi pembangunan kantor DPRD Nagekeo ini maka dapat diambil kesimpulan bahwa pemerintah Nagekeo bersama dengan DPRD Nagekeo telah menyalahi aturan dalam pengadaan lahan bagi pembangunan kantor DPRD Nagekeo. Sementara itu jika dana yang dikeluarkan sejak Tahun 2007 hingga Tahun 2009, sedangkan pada Tahun 2008 terjadi Pilkada dan Johanis S. Aoh menjadi Bupati Nagekeo menggantikan Penjabat Bupati Elias Djo, berarti Johanis S. Aoh mengetahui adanya aliran dana tersebut. Jika dugaan praktek KKN dan penyalahgunaan wewenang terbukti benar, sementara terbukti telah ada penyimpangan regulasi, maka konflik tanah pembangunan kantor DPRD Nagekeo ini dapat dianggap sebagai sarana konspirasi politik yang merugikan negara antara Penjabat Bupati Nagekeo 2007-2008 (Bupati Nagekeo Saat Ini, 2013-2018), Ketua DPRD Nagekeo 2007-2008 (Wakil Bupati saat ini, 2013-2018), dan Bupati Nagekeo 20082013.

\section{Kesimpulan}

DOB cenderung tertinggal dari berbagai aspek dibandingkan daerah induk memang secara harafiah tidak bisa dibantah, namun dengan adanya konflik, terutama konflik tanah yang akhirnya menunda dilakukannya pembangunan infrastruktur menjadikan DOB semakin jauh tertinggal. Pada akhirnya tujuan mulia otonomi yang diinginkan menjadi tidak terwujud. Kesimpulan umum yang dapat diambil dari pembahasan diatas adalah sebagai berikut :

1. Pemekaran Daerah dan penerapan otonomi daerah tidak diiringi dengan adanya pendidikan politik bagi para elit dan politik lokal, sehingga peluang terjadinya kesalahan dalam praktek birokrasi sangat besar terjadi. Hal ini terwujud dalam kesalahan pelaksanaan pengadaan tanah bagi kepentingan umum di Nagekeo, dalam konteks pembangunan kantor DPRD Nagekeo

2. Selaras dengan hasil evaluasi Pelaksanaan Otonomi Daerah oleh LIPI Tahun 2007 dan UNDP Tahun 2008, menunjukkan bahwa desentralisasi dengan bentuk otonomi daerah di Indonesia turut mendesentralisasikan praktek KKN. Data Kemendagri tahun 

2014, 327 Kepala Daerah terjerat kasus KKN, $86 \%$ melakukan Korupsi. Sehingga dengan mencerna konflik tanah pembangunan kantor DPRD Nagekeo dan berbagai proses yang melatarinya, tidaklah salah jika dugaan KKN dapat disematkan dalam konflik ini.

3. Tudingan desentralisasi di Indonesia telah melahirkan rajaraja kecil di daerah dapat dilihat dalam prakteknya dalam konflik tanah ini. Ketika kepala daerah dan legislatif daerah "bersatu" dan memanipulasi konflik dan anggaran, dengan menjadikan tanah yang memiliki nilai profit tinggi sebagai objek "bancakan".

4. Konflik tanah pembangunan Kantor DPRD Nagekeo menjadi contoh menguatnya kekuatan masyarakat dalam hal ini masyarakat suku untuk berani melawan pemerintah dan negara yang cenderung hadir sebagai monster raksasa yang menakutkan. Hal ini merupakan cerminan demokrasi Indonesia pasca runtuhnya Orde Baru yang represif.

5. Konflik ini menjadi catatan bagi pemerintah pusat untuk segera melakukan landreform sehingga praktek-praktek manipulasi hingga KKN dengan tanah sebagai objek d daerah, terutama DOB, dapat dihindarkan.
Meskipun pada akhirnya persoalan utama yang jadi penyebabnya adalah penerapan otonomi daerah seluas-luasnya sehingga kepala daerah hadir menjadi satu-satunya kekuatan di daerah. Sehingga kepala daerah menjalankan kekuasaan dan kewenangan dengan lebih mengedepankan kepentingan pribadi dan kelompok, dengan pola yang menghalalkan segala cara tanpa mengedepankan aspek prosedural dan lebih jauh tujuan otonomi daerah itu sendiri. Sehingga tidaklah heran jika pada akhirnya kepala daerah dituding sebagai raja kecil di daerah. Menyadari persoalan ini maka sudah seharusnya pemerintah pusat mengkaji kembali penerapan otonomi daerah, dengan menarik kembali kewenangankewenangan tertentu yang berkaitan dengan kepentingan nasional seperti halnya persoalan pertanahan ini. Selain itu perlu dilakukannya mekanisme maupun proses pengawasan yang lebih ketat oleh pemerintah pusat dengan menempatkan pemerintah provinsi sebagai wakil pusat, yang bertugas mengawasi kepala daerah yang arogan, dan cenderung sebagai raja kecil di daerah. Sehingga penerapan otonomi daerah menjadi lebih bertanggungjawab, dan kemandirian ekonomi daerah lebih realistis untuk dicapai.

\section{Daftar Pustaka}

Afrizal. 2006. Sosiologi Konflik Agraria Protes-protes Agraria dalam Masyarakat Indonesia Kontemporer. Padang : Andalas University Press. 

Clegg, Kendra, 2005. Dari Nasionalisasi ke Lokalisasi: Otonomi Daerah di Lombok dalam Desentralisasi Globalisasi dan Demokrasi Lokal, editor Jamil Gunawan, Jakarta: LP3ES.

George, J, Aditjondro,1993. Dimensi-Dimensi Politis Sengketa Tanah, Makalah Latihan Analisis Sosial Tanah. Medan.

Harsono, Boedi. 2012. Hukum Agraria Indonesia, Himpunan Peraturan-Peraturan Hukum Tanah, Jakarta: Djambatan.

Harmantyo, Djoko. Pemekaran Daerah Dan Konflik Keruangan Kebijakan Otonomi Daerah dan Implementasinya di Indonesia, MAKARA, SAINS, VOL. 11, NO. 1, APRIL 2007: 16-22.

Makagansa, HR. 2008. Tantangan Pemekaran Daerah, Jogjakarta : FuSpAd.

Santoso, Urip. 2005. Hukum Agraria dan Hak-hak atas Tanah. Jakarta : Prenada Media.

Sutedi, Adrian, 2009. Peralihan Hak atas Tanah dan Pendaftarannya. Jakarta: Penerbit Sinar Grafika.

SW sumardjono, Maria. 2009. Mediasi Konflik Tanah. Penerbit Buku Kompas : Jakarta 2001.Kebijakan Pertanahan Antara Regulasi Dan Implementasi. Jakarta : PT. Kompas Media Nusantara.

Syarief, Elza. Menuntaskan Konflik Pertanahan Melalui Pengadilan Khusus Pertanahan. Jakarta : Kepustakaan Popular Gramedia, 2012.

Wignosubroto, Soetandyo. 2005. Pasang Surut Otonomi Daerah, Sketsa Perjalanan 100 Tahun, Jakarta ; Institute For Local Development

Wiradi, Gunawan. 2000. Reforma Agraria : Perjalanan yang Belum Berakhir. Yogyakarta : Insist

\section{Lembar Negara}

Peraturan Presiden Nomor 71 Tahun 2012 Tentang Penyelenggaraan Pengadaan Tanah Bagi Kepentingan Umum.

Perpres RI Nomor 40 Tahun 2014 Tentang Perubahan Atas Perpres No 71 Tahun 2012 Tentang Penyelenggaraan Pengadaan Tanah Bagi Kepentingan Umum. 



\section{Sumber Lain}

Hasil Wawancara Dengan Ketua LPA Lape (Lembaga Pemangku Adat Suku Lape), Philipus F. Libha. Tanggal 12 Oktober 2014.

Hasil Wawancara Dengan Elias Djo (Bupati Nagekeo). Tanggal 17 Oktober 2014.

Hasil Wawancara Dengan Arkadius V. Doy (Staf Bagian Administrasi Pemerintahan Nagekeo). Tanggal 17 Oktober 2014.

Kamus Besar Bahasa Indonesia.

Laporan Tim Analisis dan Evaluasi Hukum tentang Pemekaran Wilayah BPHN.

Putusan pengadilan dalam Data Perkara Perdata Nomor 2/PDT. G/2009/PN. BJW.

Sejarah Nasional Provinsi Nusa Tenggara Timur.

Suara Pembaruan edisi Selasa, 12 Agustus 2014. hal. 30.

Tesis Fransiskus X. Gian Tue Mali, Negara Vs Masyarakat : Studi Kasus Konflik Tanah

Di Kabupaten Nagekeo, Provinsi Nusa Tenggara Timur, 2015, Di Universitas Nasional.

www.sergapntt.com edisi 26 April 2014. (diakses pada 12 desember 2014). 